\title{
IN-VITRO EVALUATION OF DIETS CONTAINING CRUDE GLYCEROL AS A SUBSTITUTE FOR CORN WITH SOME ADDITIVES
}

\author{
M.A. Hanafy ${ }^{1}$; Mervat S.H. Youssef ${ }^{2}$; Azza M. Badr²; Wafaa M.A. Ghoneem ${ }^{1}$ and M.R. \\ Rashid $^{2}$
}

${ }^{1}$ Animal Production Department, Faculty of Agriculture, Cairo University, Giza, Egypt.

${ }^{2}$ Regional Center for Food and Feed, Agricultural Research Center, Giza, Egypt.

(Received 14/6/2015, accepted 15/7/2015)

\section{SUMMARY}

$\mathrm{I}$ $n$ vitro studies were carried out to investigate the effect of using crude glycerol (biodiesel co-product) as a substitute for yellow corn with some feed additives. Corn comprising $30 \%$ of the whole diet was substituted by crude glycerol at four levels $(0,25,50$ and $75 \%)$ with three types of additives; buffer $\left(\mathrm{NaHCO}_{3} \& \mathrm{MgO}\right)$, dry yeast (Saccharomyces cerevisiea) and fibrolytic enzymes. In vitro dry matter disappearance (IVDMD), organic matter disappearance (IVOMD) and total gas production (GP) were studied. Crude glycerol substitution at $25 \%$ significantly increased $(\mathrm{P}<0.05)$ IVDMD, IVOMD and GP values, while 50 and $75 \%$ glycerol significantly decreased $(\mathrm{P}<0.05)$ IVOMD and GP values compared with control. No significant difference was observed for IVDMD value when crude glycerol was included at $50 \%$ of yellow corn. Addition of $4 \mathrm{~g} / \mathrm{kg}$ DM of either fibrolytic enzymes or dry yeast significantly increased ( $\mathrm{P}<0.05)$ IVDMD by 6.5 and $6 \%$, IVOMD by 6 and $4 \%$ and GP by 15.8 and $11.5 \%$, respectively. On the other hand, buffer addition had no effect on measured parameters. Using high level of fibrolytic enzymes or dry yeast $(6 \mathrm{~g} / \mathrm{kg} \mathrm{DM})$ significantly increased $(\mathrm{P}<0.05)$ IVDMD, IVOMD and GP values for 25 and 50\% glycerol compared with the lower level (4 $\mathrm{g} / \mathrm{kg} \mathrm{DM}$ ). In conclusion, crude glycerol in combination either with $6 \mathrm{~g} / \mathrm{kg}$ DM fibrolytic enzyme (ALLZYME ${ }^{\mathrm{TM}}$ ) or dry yeast (Saccharomyces cerevisiea) could replace up to $50 \%$ of the yellow corn equivalent to $15 \%$ of the whole dietary DM.

Keywords: Crude glycerol, fibrolytic enzymes, dry yeast and buffer.

\section{INTRODUCTION}

Grains, specially yellow corn, are mainly used in ruminant, poultry and fish rations, resulting in great competition with human diets especially in Egypt. The feed gap between requirements and production forced the nutritionists to use alternative feed resources. Glycerol which is a biodiesel energy co-product could be used as an alternative energetic feed resource that is not needed for further purification in food, pharmaceutical, and cosmetic industries (Thompson and He, 2006).

Recently, Donkin et al. (2009) indicate that glycerol can replace corn grain as much as $15 \%$ in diets for dairy animals. Abo El-Nor et al. (2010) observed that corn substitution with glycerol at low level (36 $\mathrm{g} / \mathrm{kg}$ DM) had no adverse effect on digestibility of DM, NDF and ADF compared to control. In the contrast, Khattab et al. (2012) found that substitution of $30 \%$ of corn in the feed mixture by glycerol significantly decreased $(\mathrm{P}<0.05)$ in vitro dry matter and organic matter disappearance.

Early studies concluded that glycerol was entirely fermented to propionate (Johns, 1953 and Garton et al., 1961) which in turn, serves as a glucogenic precursor, supplying 32 to $73 \%$ of the glucose demands in ruminants (Seal and Reynolds, 1993). In this context, Carvalho et al. (2011) studied the effect of glycerol inclusion at $110 \mathrm{~g} / \mathrm{kg}$ of DM in the diet of dairy cows during the dry period on ruminal fermentation pattern where they found an increase in the proportion of propionate and butyrate at the expense of acetate.

Some exogenous feed enzymes that contain fibrolytic activities may help in enhancing fiber digestion in the rumen (Kung et al., 2000), which could lead to improve feed conversion efficiency. In dairy goats, Khattab et al. (2012) stated that feeding glycerol with $4 \mathrm{~g} / \mathrm{kg}$ DM fibrolytic enzyme improved nutrients digestibility of DM, OM, CP, NDF, ADF and milk production compared to feeding glycerol without additives. On the other hand, Haddad and Goussous (2005) and Kholif and Khorshed (2006) found that 


\section{Hanafy et al.}

digestibility of $\mathrm{OM}, \mathrm{CP}$ and $\mathrm{CF}$ were significantly increased with yeast addition to goats or lambs rations at 2.5 or $3 \mathrm{~g} / \mathrm{h} / \mathrm{d}$. Beside that buffers in dairy rations have been recommended primarily to avoid depression of milk fat content; control ruminal acidity and to avoid reduction in dry matter intake (Doepel and Hayirli, 2011).

The aim of this in-vitro study was to: (1) Evaluate the substitution of corn with different levels of crude glycerol. (2) Use of some feed additives with glycerol to enhance IVDMD, IVOMD and gas production in comparison to corn.

\section{MATERIALS AND METHODS}

\section{Experimental design:}

This study was carried out at Regional Center for Foods and Feeds (RCFF), Agricultural Research Center (ARC), Giza, Egypt. Crude glycerol (biodiesel co-product) was used as a substitute for yellow corn at four levels $(0,25,50$ and $75 \%)$ to determine the in vitro dry matter disappearance (IVDMD), in vitro organic matter disappearance (IVOMD) and total gas production (GP). Substitution levels were carried out with three additives included; buffer $\left(\mathrm{NaHCO}_{3} \& \mathrm{MgO}\right)$, dry yeast and fibrolytic enzymes. Additive levels were $4 \mathrm{~g} / \mathrm{kg} \mathrm{DM}$ either for dry yeast or fibrolytic enzymes and $0.5 \% \mathrm{NaHCO}_{3}+0.5 \%$ $\mathrm{MgO}$ of dietary DM. Dry live yeast Saccharomyces cerevisiea: $1 \times 10^{10}$ cell/gram (Pro-Bio-Fair $^{\mathrm{TM}}$ ) and fibrolytic enzymes (ALLZYME ${ }^{\mathrm{TM}} \mathrm{SSF}$ containing per gram: 300 standard phytase units, 700 protease unit, 40 carboxymethyl cellulase units, 100 xylanase units, 200 beta glucanase units, 30 fungal amylase units, and 4000 pectinase units). Another in-vitro study was carried out to investigate the effect of two levels (4 and $6 \mathrm{~g} / \mathrm{kg} \mathrm{DM}$ ) of two additives (dry yeast and fibrolytic enzymes) with two glycerol substitution levels (25 and $50 \%)$.

\section{In vitro incubation:}

Piston-pipettes (glass syringes, $100 \mathrm{ml}$ volume) with capillary attachment, were used (5 pistonpipettes per each treatment) to determine IVDMD, IVOMD and GP. The procedures of the in vitro technique were carried out according to Menke et al. (1979). About $200 \mathrm{mg}$ of samples (on DM basis) were weighed and placed into piston-pipettes. Then $30 \mathrm{ml}$ of rumen liquor medium-mixture (one part of liquor was mixed with two parts of the medium in a woulff-bottle kept at $39^{\circ} \mathrm{C}$ in a water bath and stirred by a magnetic stirrer under $\mathrm{CO}_{2}$ atmosphere) were added using an automatic pipette. Any gas bubbles in the syringes were removed, the plastic clip on the silicon tube closed, the position of the piston recorded, and the syringes placed in the incubator for $48 \mathrm{hrs}$.

Rumen liquor was obtained from males mature sheep fed $50 \%$ clover hay and $50 \%$ concentrate mixture. Whole rumen content was obtained before the morning feed using a stomach rubber tube. Rumen liquor was squeezed through four layers of gauze and the fluid was kept in a pre-warmed thermos flask. The experimental rations are presented in Table (1).

Table (1): Feed ingredients of experimental rations.

\begin{tabular}{lcccc}
\hline \multirow{2}{*}{ Item } & \multicolumn{4}{c}{ Experimental rations } \\
\cline { 2 - 4 } & G0 & G25 & G50 & G75 \\
\hline Ingredient, \% of DM & 30 & 22.5 & 15 & 7.5 \\
Yellow corn & 9.3 & 10.2 & 11.1 & 12.3 \\
Soybean meal & 6.6 & 9.3 & 11.7 & 13.5 \\
Cottonseed meal & 11.1 & 7.5 & 4.2 & 1.2 \\
Wheat bran & 0 & 7.5 & 15 & 22.5 \\
Glycerin & 1.5 & 1.5 & 1.5 & 1.5 \\
Minerals & 1.5 & 1.5 & 1.5 & 1.5 \\
Vitamins & 40 & 40 & 40 & 40 \\
Egyptian clover hay & & & & \\
\hline
\end{tabular}




\section{Analytical procedures:}

Chemical analyses of samples were carried out according to the methods of AOAC, (2012). Neutral detergent fiber (NDF), acid detergent fiber (ADF) and acid detergent lignin (ADL) were determined according to Van Soest et al. (1991).In vitro DM and OM disappearances and GP were determined according to Menke et al. (1979).

\section{Statistical analysis:}

Data were statistically analyzed by the least square procedure of the General Linear Model Program of SAS (2009) according to procedures outlined by Snedecor and Cochran (1982). Fixed models, one, two and three-ways analysis of variance, were used. Firstly, one way analysis was used to evaluate crude glycerol substitution without additives on IVDMD, IVOMD and GP, according to the following model:

$$
\mathbf{y}_{i j}=\boldsymbol{\mu}+\mathbf{s}_{\mathbf{i}}+\mathbf{e}_{\mathbf{i j}}
$$

Where $\mathbf{y}_{\mathbf{i j}}$ is the $\mathrm{j}^{\text {th }}$ sample of the $\mathrm{i}^{\text {th }}$ substitution level, $\boldsymbol{\mu}$ isthe overall mean, $\mathbf{S}_{\mathbf{i}}$ is the fixed effect of the $\mathrm{i}^{\text {th }}$ substitution level $(\mathrm{i}=1,2,3,4 ; 1=0 \%, 2=25 \%, 3=50 \%$ and $4=75 \%)$ and $\mathbf{e}_{\mathbf{i j}}$ is the random error assumed to be normally and independently distributed.

Secondly, two-way analysis of variance was used to examine the effect of substitution levels, different additives and the interactions between them, according to the following model:

$$
\mathbf{y}_{\mathbf{i j k}}=\boldsymbol{\mu}+\mathbf{S}_{\mathbf{i}}+\mathbf{A}_{\mathbf{j}}+(\mathbf{S} . \mathbf{A})_{\mathbf{i j}}+\mathbf{e}_{\mathbf{i j k}}
$$

Where $\mathbf{y}_{\mathbf{i j k}}, \boldsymbol{\mu}, \mathbf{S}_{\mathbf{i} \text { and }} \mathbf{e}_{\mathbf{i j}}$ are the same as the one way model while $\mathbf{A}_{\mathbf{j}}$ is the fixed effect of the $\mathrm{j}^{\text {th }}$ additive $\left(\mathrm{j}=1,2,3 ; 1=\right.$ buffer, $2=$ dry yeast and $3=$ fibrolytic enzymes) and $(\mathbf{S} . \mathbf{A})_{\mathbf{i j}}$ is the interaction between the $\mathrm{i}^{\text {th }}$ substitution level and the $\mathrm{j}^{\text {th }}$ additive.

Thirdly, three-way analysis of variance was used to examine the effect of substitution levels, different additives, additive level and the interactions between them, according to the following model:

$$
\left.\mathbf{y}_{\mathbf{i j k n}}=\boldsymbol{\mu}+\mathbf{S}_{\mathbf{i}}+\mathbf{A}_{\mathbf{j}}+L_{k}+\text { (S.A.L }\right)_{i j k}+\mathbf{e}_{\mathbf{i j k n}}
$$

All terms where the same as the previous module except that the substitution levels were two $(25 \%$ and $50 \%$ ) and the additives were also two (dry yeast and fibrolytic enzymes) in addition to $\mathbf{L}_{\mathbf{k}}$ : the fixed effect of the $\mathrm{k}^{\text {th }}$ additive level $(\mathrm{k}=1,2 ; 1=4 \mathrm{~g} / \mathrm{kg} \mathrm{DM}$ and $2=6 \mathrm{~g} / \mathrm{kg} \mathrm{DM})$ and (S.A.L) $)_{\mathrm{ijk}}$ : the interaction between the $\mathrm{i}^{\text {th }}$ substitution level, the $\mathrm{j}^{\text {th }}$ additive and the $\mathrm{k}^{\text {th }}$ additive level.

Procedures of Duncan's New Multiple Range Test according to Duncan's, (1955) Least Square Means according to; Steel and Torrie, 1980 and Tukey's multiple comparison test according to honestly significant difference $(\mathrm{HSD})$ were used to asses significance $(\mathrm{P}<0.05)$ of differences among means.

\section{RESULTS AND DISCUSSION}

\section{Chemical composition and fiber fractions of experimental rations:}

Results of chemical composition (Table 2) indicated that contents of most nutrients were similar in all experimental rations. However, a slight increase in CF content and a decrease in NFE content were observed with rations contained crude glycerol. This could be attributed to the linear increases in cottonseed meal and the decreases in yellow corn proportions with increasing glycerol substitution level which was made to formulate iso-nitrogenous rations.

Likewise, fiber fractions were almost the same in all experimental rations except, G75 ration that contained the highest ADF and cellulose contents which may be as a result of high cottonseed meal proportion. In the contrast, Khattab et al. (2012) recorded decreases in ADF and NDF contents with rations contained glycerol.

\section{Effect of glycerol level:}

Regarding crude glycerol substitution level (Table 3), replacement of $25 \%$ yellow corn by crude glycerol had significantly higher IVDMD, IVOMD and GP values being $57.27 \%$, 61.96\% and 32.18 


\section{Hanafy et al.}

$\mathrm{ml} / 200 \mathrm{mg}$ DM compared with control and other substitution levels (50 and 75\%). No significant effect was observed for IVDMD value at 50\% crude glycerol compared with control $(54.14 \%$ and $55.14 \%$, respectively). Meanwhile, the values of IVOMD and GP $(58.56 \%$ and $27.70 \mathrm{ml} / 200 \mathrm{mg}$ DM) were significantly decreased $(\mathrm{P}<0.05)$ compared with control $(60.39 \%$ and $30.11 \mathrm{ml} / 200 \mathrm{mg} \mathrm{DM})$. The $75 \%$ replacement had the lowest IVDMD, IVOMD and GP values being 52.54\%, 56.50\% and $24.98 \mathrm{ml} / 200$ mg DM, respectively.

Data showed that increasing concentrations of crude glycerol more than $25 \%$ of corn or $7.5 \%$ of DM (G50 and G75) was associated by a decrease of IVOMD and GP values. This result could be attributed to the inhibitory effect of glycerol on ruminal fungi (Roger et al., 1992) or cellulolytic bacteria (Abo El-Nor et al., 2010). Moreover, Abo El-Nor et al. (2010) found that substitution of corn with glycerol at low level $(15 \%)$ had no negative effect on digestibility of DM, NDF and ADF using continuous fermentor compared to control. However, replacing corn by glycerol at 30 and $45 \%$ was noted to reduce digestibility of NDF and ADF compared to control (Khattab et al., 2012 and Avila-Stagno et al., 2014). In contrast, Donkin et al. (2009) found that apparent digestibility of DM and OM were increased compared with control when 5,10 and $15 \%$ of corn grains were substituted by glycerol in lactating dairy cows.

Table (2): Chemical composition of experimental rations.

\begin{tabular}{lcccc}
\hline \multirow{2}{*}{ Item } & \multicolumn{4}{c}{ Experimental rations } \\
\cline { 2 - 4 } DM, \% & G0 & G25 & G50 & G75 \\
DM basis, \% & 92.27 & 92.11 & 91.15 & 90.39 \\
OM & & & & \\
CP & 92.34 & 92.17 & 92.53 & 92.48 \\
CF & 15.59 & 16.26 & 16.18 & 15.97 \\
EE & 9.49 & 9.99 & 10.03 & 11.42 \\
NFE & 2.81 & 3.91 & 3.72 & 3.56 \\
Ash & 64.45 & 62.01 & 62.60 & 61.53 \\
Fiber fractions & 7.66 & 7.83 & 7.47 & 7.52 \\
NDF & & & & \\
ADF & 21.78 & 21.43 & 19.53 & 22.31 \\
ADL & 12.17 & 12.74 & 13.76 & 15.88 \\
Hemicellulose & 3.30 & 3.34 & 4.39 & 3.12 \\
Cellulose & 9.61 & 8.69 & 5.77 & 6.43 \\
Lignin & 8.87 & 9.40 & 9.37 & 12.76 \\
\hline
\end{tabular}

Table (3): Effect of glycerol levels and different additives on in vitro dry matter and organic matter disappearance $(\%)$ and total gas production $(\mathrm{ml} / 200 \mathrm{mg} \mathrm{DM})$.

\begin{tabular}{lccc}
\hline Item & IVDMD & IVOMD & GP \\
\hline Replacement levels & & & \\
Control (G0) & $55.14^{\mathrm{b}}$ & $60.39^{\mathrm{b}}$ & $30.11^{\mathrm{b}}$ \\
G25 & $57.27^{\mathrm{a}}$ & $61.96^{\mathrm{a}}$ & $32.18^{\mathrm{a}}$ \\
G50 & $54.14^{\mathrm{b}}$ & $58.56^{\mathrm{c}}$ & $27.70^{\mathrm{c}}$ \\
G75 & $52.54^{\mathrm{c}}$ & $56.50^{\mathrm{d}}$ & $24.98^{\mathrm{d}}$ \\
\pm SE & 0.51 & 0.54 & 0.72 \\
Additives & & & $27.05^{\mathrm{b}}$ \\
Without & $53.07^{\mathrm{b}}$ & $58.07^{\mathrm{b}}$ & $26.40^{\mathrm{b}}$ \\
Buffer & $53.10^{\mathrm{b}}$ & $57.58^{\mathrm{b}}$ & $31.34^{\mathrm{a}}$ \\
Fibrolytic enzymes & $56.53^{\mathrm{a}}$ & $61.32^{\mathrm{a}}$ & $30.17^{\mathrm{a}}$ \\
Dry yeast & $56.39^{\mathrm{a}}$ & $60.43^{\mathrm{a}}$ & 0.72 \\
tSE & 0.51 & 0.54 &
\end{tabular}




\section{Effect of additives type:}

Regarding type of additives (Table 3), the addition of $4 \mathrm{~g}$ either from fibrolytic enzymes or dry yeast $/ \mathrm{kg}$ DM had a positive significant $(\mathrm{P}<0.05)$ effects on IVDMD $(56.53 \%$ and $56.39 \%)$ and IVOMD $(61.32 \%$ and $60.43 \%)$, and GP (31.34 and $30.17 \mathrm{ml} / 200 \mathrm{mg} \mathrm{DM})$ compared with no additive treatment $(53.07 \%, 58.07 \%$ and $27.05 \mathrm{ml} / 200 \mathrm{mg} \mathrm{DM}$, respectively). However, buffer addition did not affect significantly IVDMD, IVOMD and GP values $(53.10 \%, 57.58 \%$ and $26.40 \mathrm{ml} / 200 \mathrm{mg} \mathrm{DM}$, respectively).

The positive effect of fibrolytic enzymes might be explained by creating a stable enzyme-feed complex that protects free enzymes from proteolysis in the rumen (Kung et al., 2000). Several potential modes of action have been proposed, included: 1) increasing the microbial colonization of feed particles (Yang et al., 1999), 2) enhancing attachment and /or improve access to the cell wall matrix by ruminal microorganisms which result in accelerating the rate of digestion (Nsereko et al. 2000), 3) enhancing the hydrolytic capacity of the rumen due to added enzyme activities and/or synergy with rumen microbial enzymes (New bold, 1997 and Morgavi et al., 2000) and 4) enzymes were able to degrade complex substrate to simpler ones, allowing a faster ruminal microbial colonization and fermentation (Colombatto et al., 2003).

The positive effect of dry yeast might be explained by the increase in the population and/or activity of rumen cellulolytic bacteria as mentioned by Erasmus et al. (1992) and Newbold et al. (1995) and also might increase ciliate protozoa number which represent more than $90 \%$ of rumen fibrolysis activity (Kamel et al., 2004 and Tripathi and Karim, 2011). It was mentioned also that yeast provides rumen microflora with vitamins or other growth factors or by scavenging oxygen entered the rumen (Chaucheyras-Durand et al., 2008) and might increase proleolytic bacteria counts (Yoon and Stern, 1996 and Tripathi and Karim, 2011).

Results concern fibrolytic enzyme and yeast addition are coincide with those obtained by Haddad and Goussous (2005), Kholif and Khorshed (2006) and Khattab et al. (2012).

In the contrary, Gomez-Alarcon et al. (1990) and Hristov et al. (2010) found that adding yeast at 3 $\mathrm{g} / \mathrm{h} /$ day to rations of Holstein cows did not detecte significant effects on digestibility of DM, OM, CP, $\mathrm{NDF}$ and ADF compared with control.

Results concerning buffer addition are in agreement with those obtained by Doepel and Hayirli (2011) who demonstrated that cows fed diets containing $20 \%$ steam-rolled wheat with sodium bicarbonate had no significant effect on the digestibility of DM, CP, ADF, and NDF compared with control diet.

The effect of interaction between glycerin levels and different additives on in vitro dry matter and organic matter disappearance and total gas production (Table 4) Indicated that using dry yeast as additive when $25 \%$ of corn replaced by crude glycerol had the highest $(\mathrm{P}<0.05)$ IVOMD and GP values $(63.52 \%$ and $34.25 \mathrm{ml} / 200 \mathrm{mg} \mathrm{DM}$, respectively) compared with $50 \%$ replacement level of corn $(59.60 \%$ and $29.07 \mathrm{ml} / 200 \mathrm{mg} \mathrm{DM}$, respectively) or $75 \%$ replacement level $(56.07 \%$ and $24.41 \mathrm{ml} / 200 \mathrm{mg} \mathrm{DM}$, respectively). Meanwhile, addition of fibrolytic enzymes had almost the same effect on IVOMD and GP values when corn replaced by crude glycerol either at $25 \%(63.12 \%$ and $33.72 \mathrm{ml} / 200 \mathrm{mg} \mathrm{DM}$, respectively) or $50 \%$ (63.00\% and $33.56 \mathrm{ml} / 200 \mathrm{mg} \mathrm{DM}$, respectively), but the values were significantly decreased $(\mathrm{P}<0.05)$ with $75 \%$ glycerol $(58.05 \%$ and $27.02 \mathrm{ml} / 200 \mathrm{mg}$ DM, respectively).

The addition of dry yeast or fibrolytic enzymes at low level of corn substitution by crude glycerol (25\%) could enhance digestibility, while with the higher substitution level $(50 \%)$ fibrolytic enzymes could be used as the best additive to improve digestibility and alleviate glycerol negative effects. These results are paralleled with those reported by Yang et al., (1999) and Kung et al. (2000) that exogenous feed fibrolytic enzymes could enhance fiber digestion in the rumen. In this context, Khattab et al. (2012) detected insignificant differences between goats fed glycerol with fibrolytic enzymes $(4 \mathrm{~g} / \mathrm{kg} \mathrm{DM})$ and those fed control diet in digestibility of DM, ADF and hemicellulose.

\section{Effect of additives level:}

The effects of using two levels of fibrolytic enzymes and dry yeast (4 g and $6 \mathrm{~g} / \mathrm{kg} \mathrm{DM}$ ) at $25 \%$ and $50 \%$ glycerol on In vitro dry matter and organic matter disappearance and gas production (Table 5) indicated that using high level of fibrolytic enzymes or dry yeast increased IVDMD, IVOMD and GP for $25 \%$ and 50\% glycerol level. The highest IVDMD, IVOMD and GP values recorded when high level of fibrolytic enzymes $(6 \mathrm{~g} / \mathrm{kg} \mathrm{DM})$ was added either with glycerol at $25 \%(59.52 \%, 64.37 \%$ and 35.37 $\mathrm{ml} / 200 \mathrm{mg} \mathrm{DM}$, respectively) or at $50 \%(59.27 \%, 64.05 \%$ and $34.95 \mathrm{ml} / 200 \mathrm{mg} \mathrm{DM}$, respectively) and when high level of dry yeast $(6 \mathrm{~g} / \mathrm{kg} \mathrm{DM})$ was added at $25 \%$ glycerin $(60.49 \%, 64.14 \%$ and $35.07 \mathrm{ml} / 200$ mg DM, respectively). 


\section{Hanafy et al.}

Values of IVOMD and GP of $50 \%$ glycerol diet were higher $(\mathrm{P}<0.05)$ at high level of fibrolytic enzymes $(64.05 \%$ and $34.95 \mathrm{ml} / 200 \mathrm{mg} \mathrm{DM}$, respectively) than those at high level of dry yeast $(61.23 \%$ and $31.23 \mathrm{ml} / 200 \mathrm{mg} \mathrm{DM}$, respectively). The same results obtained by Khattab et al. (2012) who stated that substituting $30 \%$ of corn by crude glycerol with fibrolytic enzymes addition significantly increased IVDMD and IVOMD compared with glycerol alone, without significant difference compared with control.

Table (4): Effect of interaction between glycerol levels and additives on in vitro dry matter and organic matter disappearance $(\%)$ and total gas production $(\mathrm{ml} / 200 \mathrm{mg} \mathrm{DM})$.

\begin{tabular}{|c|c|c|c|}
\hline Item & IVDMD & IVOMD & GP \\
\hline \multicolumn{4}{|l|}{ G0 } \\
\hline Without & $53.88^{\mathrm{cd}}$ & $59.58^{\text {bcde }}$ & $29.04^{\text {bcde }}$ \\
\hline Buffer & $52.52^{\text {def }}$ & $58.33^{\text {cdef }}$ & $27.39^{\text {cdef }}$ \\
\hline Fibrolytic enzymes & $57.95^{\mathrm{ab}}$ & $61.11^{\mathrm{abcd}}$ & $31.06^{\mathrm{abcd}}$ \\
\hline Dry yeast & $56.19^{\mathrm{abc}}$ & $62.53^{\mathrm{ab}}$ & $32.94^{\mathrm{ab}}$ \\
\hline \multicolumn{4}{|l|}{ G25 } \\
\hline Without & $55.83^{\mathrm{bc}}$ & $61.34^{\mathrm{abc}}$ & $31.36^{\mathrm{abc}}$ \\
\hline Buffer & $56.30^{\mathrm{abc}}$ & $59.85^{\text {bcde }}$ & $29.40^{\text {bcde }}$ \\
\hline Fibrolytic enzymes & $58.06^{\mathrm{ab}}$ & $63.12^{\mathrm{a}}$ & $33.72^{\mathrm{a}}$ \\
\hline Dry yeast & $58.89^{\mathrm{a}}$ & $63.52^{\mathrm{a}}$ & $34.25^{\mathrm{a}}$ \\
\hline \multicolumn{4}{|l|}{ G50 } \\
\hline Without & $50.27^{\mathrm{f}}$ & $53.56^{\mathrm{g}}$ & $21.10^{\mathrm{g}}$ \\
\hline Buffer & $52.87^{\text {def }}$ & $58.06^{\text {def }}$ & $27.05^{\mathrm{def}}$ \\
\hline Fibrolytic enzymes & $56.46^{\mathrm{abc}}$ & $63.00^{\mathrm{a}}$ & $33.56^{\mathrm{a}}$ \\
\hline Dry yeast & $56.94^{\mathrm{ab}}$ & $59.60 b c^{d e}$ & $29.07^{\text {bcde }}$ \\
\hline \multicolumn{4}{|l|}{ G75 } \\
\hline Without & $52.29^{\mathrm{def}}$ & $57.81^{\mathrm{ef}}$ & $26.70^{\mathrm{ef}}$ \\
\hline Buffer & $50.69^{\mathrm{ef}}$ & $54.07^{\mathrm{g}}$ & $21.77^{\mathrm{g}}$ \\
\hline Fibrolytic enzymes & $53.66^{\mathrm{cd}}$ & $58.05^{\mathrm{def}}$ & $27.02^{\mathrm{def}}$ \\
\hline Dry yeast & $53.53^{\text {cde }}$ & $56.07^{\mathrm{fg}}$ & $24.41^{\mathrm{fg}}$ \\
\hline$+\mathrm{SE}$ & 1.02 & 1.08 & 1.43 \\
\hline
\end{tabular}

Table (5): Effect of fibrolytic enzyme and dry yeast levels with 25 and $50 \%$ glycerol replacement on in vitro dry matter and organic matter disappearance $(\%)$ and total gas production (ml/200 mg DM).

\begin{tabular}{|c|c|c|c|c|c|}
\hline $\begin{array}{c}\text { Glycerol } \\
\text { level }\end{array}$ & Additive & $\begin{array}{c}\text { Additive } \\
\text { level }\end{array}$ & IVDMD & IVOMD & GP \\
\hline \multicolumn{6}{|l|}{$25 \%$} \\
\hline & Fibrolytic enzymes & $\mathrm{L}$ & $58.06^{\text {bcd }}$ & $63.12^{\mathrm{ab}}$ & $33.72^{\mathrm{ab}}$ \\
\hline & & $\mathrm{H}$ & $59.52^{\mathrm{ab}}$ & $64.37^{\mathrm{a}}$ & $35.37^{\mathrm{a}}$ \\
\hline & Dry yeast & $\mathrm{L}$ & $58.89^{\mathrm{abc}}$ & $63.52^{\mathrm{ab}}$ & $34.25^{\mathrm{ab}}$ \\
\hline & & $\mathrm{H}$ & $60.49^{a}$ & $64.14^{\mathrm{ab}}$ & $35.07^{\mathrm{ab}}$ \\
\hline \multicolumn{6}{|l|}{$50 \%$} \\
\hline & Fibrolytic enzymes & $\mathrm{L}$ & $56.46^{\mathrm{d}}$ & $63.00^{\mathrm{b}}$ & $33.56^{\mathrm{b}}$ \\
\hline & & $\mathrm{H}$ & $59.27^{\mathrm{ab}}$ & $64.05^{\mathrm{ab}}$ & $34.95^{\mathrm{ab}}$ \\
\hline & Dry yeast & $\mathrm{L}$ & $56.94^{\mathrm{cd}}$ & $59.60^{\mathrm{d}}$ & $29.07^{\mathrm{d}}$ \\
\hline & & $\mathrm{H}$ & $59.71^{\mathrm{ab}}$ & $61.23^{c}$ & $31.23^{\mathrm{c}}$ \\
\hline$\pm \mathrm{SE}$ & & & 0.74 & 0.45 & 0.59 \\
\hline
\end{tabular}

Means in the same column with different superscripts are significantly different $(P<0.05)$.

Low: 4 g/kg DM; High: 6 g/kg DM. 


\section{CONCLUSION}

Substitution of 25 or $50 \%$ yellow corn by crude glycerol had the potential to improve in vitro DM and OM disappearance and GP when combined either with fibrolytic enzyme (ALLZYME ${ }^{\mathrm{TM}}$ ) or dry yeast (Saccharomyces cerevisiea) and could be used as an alternative energy source in ruminant rations.

\section{REFERENCES}

Abo El-Nor, S.; A.A. Abu Ghazaleh; R.B. Potu; D. Hastings and M.S.A. Khattab (2010). Effects of different levels of glycerol on rumen fermentation and bacteria. Anim. Feed sci. Technol., 162: 99105.

AOAC (2012).Official Methods of Analysis of AOAC International, 19 ${ }^{\text {th }}$ Ed. Vol.1, "Animal feed". Maryland, USA, chapter 4:1-77.

Avila-Stagno, J.; A.V. Chaves; G.O. Ribeiro Jr.; E.M. Ungerfeld and T.A. McAllister (2014). Inclusion of glycerol in forage diets increases methane production in a rumen simulation technique system. Br. $\mathrm{J}$. Nutr., 111: 829-835.

Carvalho, E.R.; N.S. Schmelz-Roberts; H.M. White; P.H. Doane and S.S. Donkin (2011). Replacing corn with glycerol in diets for transition dairy cows. J. Dairy Sci., 94: 908-916.

Chaucheyras-Durand, F.; N.D. Walker and A. Bach (2008). Effects of active dry yeasts on the rumen microbial ecosystem: past, present and future. Anim. Feed Sci. Technol., 145: 5-26.

Colombatto, D.; F.L. Mould; M.K. Bhat; D.P. Morgavi; K.A. Beauchemin and E. Owen (2003). Influence of fibrolytic enzymes on the hydrolysis and fermentation of pure cellulose and xylan by mixed ruminal microorganisms in vitro. J. Anim. Sci., 81:1040-1050.

Doepel, L. and A. Hayirli (2011). Exclusion of dietary sodium bicarbonate from a wheat-based diet: effects on milk production and ruminal fermentation. J. Dairy Sci., 94: 370-375.

Donkin, S.S.; S.L. Koser; H.M. White; P.H. Doane and M.J. Cecava (2009). Feeding value of glycerol as a replacement for corn grain in rations fed to lactating dairy cows. J. Dairy Sci., 92: 5111-5119.

Duncan, D.B. (1955). Multiple range and multiple F tests. Biometrics, 11: 1-42.

Erasmus, L.J.; P.M. Botha and A. Kistner (1992).Effect of yeast culture supplement in production, rumen fermentation and duodenal nitrogen flow in dairy cows. J. Dairy Sci., 75: 3056-3065.

Garton, G.A.; A.K. Lough and E.Vioque, (1961). Glyceride hydrolysis and glycerol fermentation by sheep ruminal contents.J. Gen. Microbiol,, 25: 215-225.

Gomez-Alarcon, R.A.; C. Dudas and J.T. Huber (1990). Influence of cultures of Aspergillusoryzae on rumen and total tract digestibility of dietary components. J. Dairy Sci., 73:703-710.

Haddad, S.G. and S.N. Goussous (2005). Effect of yeast culture supplementation on nutrient intake, digestibility and growth performance of Awassi lambs. Anim. Feed Sci. Technol., 118:343-348.

Hristov, A.N.; G. Varga; T. Cassidy; M. Long; K. Heyler; S.K.R. Karnati; B.Corl; C.J. Hovde and I. Yoon (2010). Effect of Saccharomyces cerevisiae fermentation product on ruminal fermentation and nutrient utilization in dairy cows. J. Dairy Sci., 93: 682-692.

Johns, A.T. (1953). Fermentation of glycerol in the rumen of sheep. N. Z. J. Sci. Technol., 35: 262-269.

Kamel, H.E.M., J. Sekine; A.M. El-Waziry and M.H.M. Yacout (2004). Effect of Saccharomyces cerevisiae on the synchronisation of organic matter and nitrogen degradation kinetics and microbial nitrogen synthesis in sheep fed Berseem hay (Trifolium alexandrinum). Small Rumin. Res., 52: 211216.

Khattab, M.S.; S.A.H. Abo El-Nor; H.M.A. El-Sayed; N.E. El-Bordeny; M.M. Abdou and O.H. Matloup (2012).The effect of replacing corn with glycerol and fibrolytic enzymes on the productive performance of lactating goats. International J. Dairy Sci., 7: 95-102.

Kholif, S.M. and M.M. Khorshed (2006).Effect of yeast or selenized yeast supplementation to rations on 


\section{Hanafy et al.}

the productive performance of lactating buffaloes. Egypt. J. Nutrition and Feeds, 9:193-205.

Kung, L.Jr. ; R.J. Treacher; G.A. Nauman; A.M. Smagala; K.M. Endres and M.A. Cohen (2000). The effect of treating forages with fibrolytic enzymes on nutritive value and lactation performance of dairy cows. J. Dairy Sci., 83:115-122.

Menke, K.H.; L. Raab; A. Salewski; H. Steingass; D. Fritz and W. Schneider (1979). The estimation of digestibility and metabolizable energy content of ruminant feedstuffs from the gas production when they are incubated with rumen liquor in vitro. In: J. Agric. Sci. (Cambridge), 92:217-222.

Morgavi, D.P.; K.A. Beauchemin; V. Nsereko; L.M. Rode; A.D. Iwaasa; W.Z. Yang; T.A. McAllister and Y. Wang (2000). Synergy between ruminal fibrolytic enzymes and enzymes from Trichoderma longibrachiatum. J. Dairy Sci., 83: 1310-1321.

Newbold, C.J (1997). Proposed mechanisms for enzymes as modifiers of ruminal fermentation. In: "Proceedings of the 8th Annual Florida Ruminant Nutrition Symposium", Gainesville, Florida, USA, pp.146-159.

Newbold, C.J.; R.J. Wallance; X.B. Chen and F.M. McIntosh (1995). Different strains of Saccharomyces cerevisiae differ in their effect on ruminal bacterial nubers in vitro and in sheep. J. Anim. Sci., 73:1811-1818.

Nsereko, V.L.; D.P. Morgavi; L.M. Rode; K.A. Beauchemin and T.A. McAllister (2000). Effects of fungal enzyme preparations on hydrolysis and subsequent degradation of alfalfa hay fiber by mixed rumen microorganisms in vitro. Anim. Feed Sci. Technol., 88: 153-170.

Roger, V.; G. Fonty; C. Andre and P. Gouet (1992). Effects of glycerol on the growth, adhesion and cellulolytic activity of rumen cellulolytic bacteria and anaerobic fungi.Currant .Microbiol., 25: 197201.

SAS, (2009). SAS. User’s Guide: Statistics. Version 9.2.SAS Inst. Inc., Cary, NC., USA.pp. 7869.

Seal, C.J. and C.K. Reynolds (1993). Nutritional implications of gastrointestinal and liver metabolism in ruminants.Nutr. Res. Rev., 6: 185-208.

Snedecor, G.W. and W.G. Cochran (1982).Statistical Methods. $7^{\text {th }}$ ed. Iowa State Unvi.Press, Ames, Iowa, USA, 213p.

Steel, R. G. D. and J. H. Torrie (1980). Principles and procedures of statistical analysis. $2^{\text {nd }}$ ed. Mc GrowHill; London.

Thompson, J.C. and B. He (2006). Characterization of crude glycerol from biodiesel production from multiple feedstocks. Applied Engineering of Agriculture, 22: 261-265.

Tripathi, M.K. and S.A. Karim (2011).Effect of yeast cultures supplementation on live weight change, rumen fermentation, ciliate protozoa population, microbial hydrolytic enzymes status and slaughtering performance of growing lamb. Livestock Science, 135: 17-25.

Van Soest, P.J.; J.B. Robertson and B.A. Lewis (1991). Methods for dietary fiber, neutral detergent fiber, and nonstarch polysaccharides in relation to animal nutrition. J. Dairy Sci., 74: 3583-3597.

Yang, W.Z.; K.A. Beauchemin and L. M. Rode (1999). Effects of an enzyme feed additive on extent of digestion and milk production of lactating dairy cows. J. Dairy Sci., 82:391-403.

Yoon, I. K. and M. D. Stern (1996). Effects of Saccharomyces cervisiae and Aspergillusoryzae cultures on ruminal fermentation in dairy cows. J. Dairy Sci., 79: 411-417. 
التقييم المعملى لعلائق تحتوى على الجليسرول الخام كإحلال من الأذرة مع بعض الإضافات

\author{
محمد أحمد حنفي1، مرفت سيد حسن يوسف2، عزة محمد بدر2، وفاء مصطفى على غنيم1، محمد رشيد سلامةّ2.

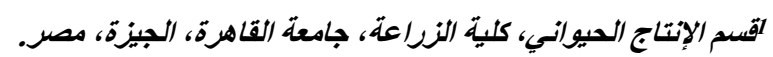 \\ ملمركز الإقليمي للأغنية والأعلاف، مركز البحوث النزراعية، الجبزة، مصر.
}

تم إجراء عدة تجارب معملية in vitro لدراسة تأثئير استخدام الجليسرول الخام كبديل للأذرة الصفر اء مع بعض إضافافات الأعلاف. تم

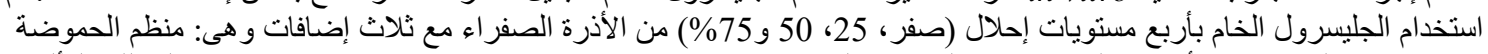

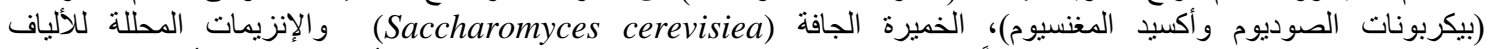

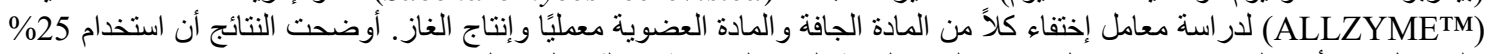

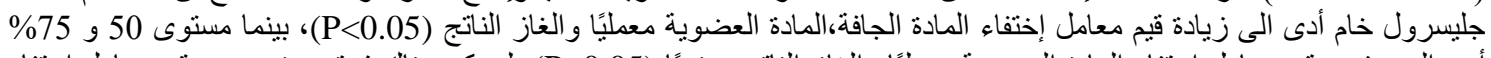

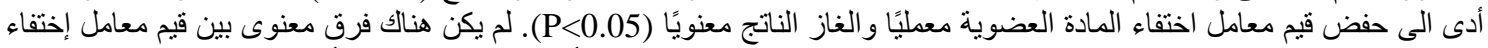

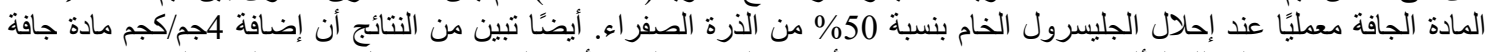

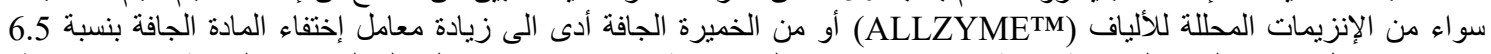

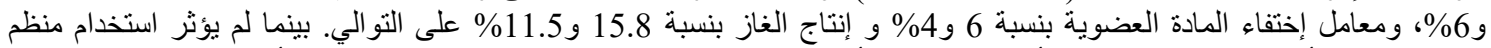

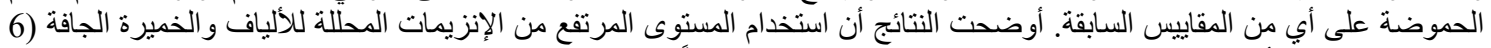

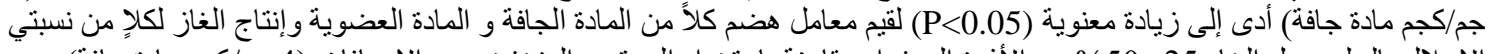

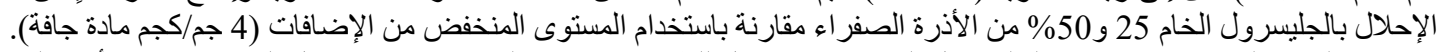

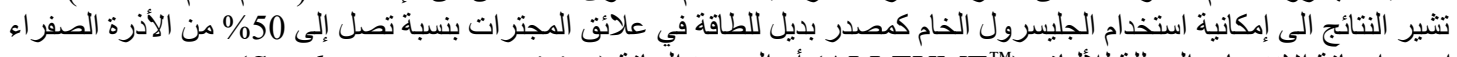

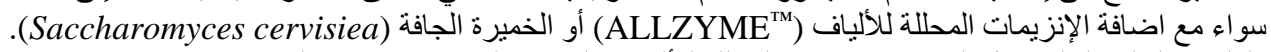
الكلمات الدالة: الجليسرول الخام ، الإنزيمات المحللة للألياف، الخميرة الجافة و منظمات الحمات الحموضة. 